\title{
Determination and validation method of molybdenum by adsorptive catalytic stripping voltammetry at lead film electrode
}

\author{
Nail Deniz ${ }^{\oplus 1}$, Lokman Liv ${ }^{\oplus 2}$ and Nuri Nakiboğlu ${ }^{10 *}$ \\ ${ }^{1}$ Department of Chemistry, Faculty of Arts and Sciences, Balıkesir University, Balıkesir, \\ Türkiye \\ ${ }^{2}$ Electrochemistry Laboratory, TÜBITAK UME (National Metrology Institute), \\ P.Box: 41470 Gebze-Kocaeli, Türkiye
}

(Received April 04, 2017; Revised June 23, 2017; Accepted July 2, 2017)

\begin{abstract}
A new, selective, sensitive and accurate method for determination of molybdenum by adsorptive catalytic stripping voltammetry was described. The method is based on catalytic reduction of adsorbed Mo(VI)ARS complex onto the lead film electrode in the presence of chlorate used as oxidizing agent. The instrumental and solution parameters affecting the peak current were optimized. The calibration graph is linear between 2.65$20.00 \mu \mathrm{g} / \mathrm{L} \mathrm{Mo}(\mathrm{VI})$ and limit of detection is estimated as $0.79 \mu \mathrm{g} / \mathrm{L}$. The proposed method was applied to drinking water samples with satisfactorily recovery results and the uncertainty calculation of the method was performed.
\end{abstract}

Keywords: Molybdenum; Alizarin Red S; adsorptive catalytic stripping voltammetry; lead film electrode. (C) 2017 ACG Publications. All rights reserved.

\section{Introduction}

Molybdenum is used the most in metallurgy area such as alloys, superalloys, stainless steel, structural steel, tool and high speed steels [1]. Besides molybdenum is essential element that acts as catalytically active along enzyme catalysis reactions. There are five Mo-dependent enzymes, four of them are for humans, one of them is for plants [2]. Molybdenum deficiency causes to functioning disorder of sulfite oxidase, affecting easily toxic reactions of sulfite in foods and tooth decay [1]. World Health Organization prefers to $2 \mu \mathrm{g} / \mathrm{kg}$ molybdenum intake daily for humans [3]. The molybdenum limits in drinking water released by The U.S. Environmental Protection Agency are 10 $\mu \mathrm{g} / \mathrm{L}$ for children and $50 \mu \mathrm{g} / \mathrm{L}$ for adults and for irrigation water released by The United Nations Food and Agriculture Organization is $10 \mu \mathrm{g} / \mathrm{L}$ [4].

Due to simple, rapid, cheap and sensitive features of voltammetric techniques, the researchers have tended to voltammetric methods. The complexing agents are generally used for voltammetric determination of molybdenum to form stable Mo(VI)-organic ligand complexes and all methods are based on adsorption controlled electrode reaction. These ligands are oxine [5-7], methyl thymol blue [8,9], chloranilic acid [10-14], a-benzoin oxime [15-18], cupferron [19,20], dihydroxynaphtalene [21],

*Corresponding author: Phone: (+90) 266612 1000-1113, Fax: : (+ 90) 2666121515

E-Mail: nnuri@balikesir.edu.tr 
p-cresol derivative [22], 1,10-phenanthroline [23], methyl orange [24], 8-hydroxyquinoline [25], pyrogallol red [26,27], mandelic acid [28], cetyltrimethylammonium bromide (CTAB) [29], tiron [30], morin [31], alizarin violet [32], alizarin red s [4,33,34] and azo compounds [35]. These methods were summarized in Table 1.

Mercury based methods have a great drawback owing to toxicity effect for environment and humans. Therefore there has been a tendency to the using of solid electrodes. The dependence on our best knowledge, there is no comprehensive study for voltammetric determination of molybdenum in terms of validation and using Mo-ARS-chlorate catalytic system. It is aimed to develop new, simple, sensitive and selective voltammetric determination method of molybdenum and also to calculate several validation parameters and uncertainty of the method.

Table 1. Summary of the voltammetric methods for determination of molybdenum

\begin{tabular}{|c|c|c|c|c|c|}
\hline Method & Electrode & Ligand & $\begin{array}{c}\text { Analytical } \\
\text { Range }\end{array}$ & $\begin{array}{l}\text { Limit of } \\
\text { Detection }\end{array}$ & Reference \\
\hline DPSV & $\mathrm{HgFE}$ & Oxine & $0-300 \mu \mathrm{g} / \mathrm{L}$ & $0.5 \mu \mathrm{g} / \mathrm{L}$ & 5 \\
\hline LSSV & SMDE & Oxine & $0.01-5 \mathrm{nM}$ & $0.0017 \mathrm{nM}$ & 6 \\
\hline SWSV & HMDE & Oxine & $0-150 \mu \mathrm{g} / \mathrm{L}$ & $0.1 \mu \mathrm{g} / \mathrm{L}$ & 7 \\
\hline DPSV & HMDE & Methyl thymol blue & $0.01-150 \mu \mathrm{g} / \mathrm{L}$ & $2 \mathrm{ng} / \mathrm{L}$ & 8 \\
\hline DPSV & HMDE & Methyl thymol blue & - & - & 9 \\
\hline DPSV & HMDE & Chloranilic acid & $0-50 \mu \mathrm{g} / \mathrm{L}$ & $0.07 \mu \mathrm{g} / \mathrm{L}$ & 10 \\
\hline DPSV & $\mathrm{HgFE}$ & Chloranilic acid & $2-200 \mathrm{nM}$ & $83 \mathrm{pM}$ & 11,12 \\
\hline SWSV & $\mathrm{BiFE}$ & Chloranilic acid & $5-50 \mu \mathrm{g} / \mathrm{L}$ & $0.2 \mu \mathrm{g} / \mathrm{L}$ & 13 \\
\hline DPSV & HMDE & Chloranilic acid & $0-200 \mu \mathrm{g} / \mathrm{L}$ & $0.4 \mu \mathrm{g} / \mathrm{L}$ & 14 \\
\hline DPSV & HMDE & a-benzoin oxime & $0-0.2 \mu \mathrm{g} / \mathrm{L}$ & $20 \mathrm{ng} / \mathrm{L}$ & 15 \\
\hline DPSV & HMDE & a-benzoin oxime & - & - & 16 \\
\hline LSSV & CMCPE & a-benzoin oxime & $0.1-80 \mu \mathrm{M}$ & $20 \mathrm{nM}$ & 17 \\
\hline LSSV & HMDE & a-benzoin oxime & $2-100 \mathrm{nM}$ & $0.35 \mathrm{nM}$ & 18 \\
\hline DPSV & HMDE & Cupferron & $0.1-20 \mu \mathrm{g} / \mathrm{L}$ & $0.06 \mu \mathrm{g} / \mathrm{L}$ & 19 \\
\hline DPSV & HMDE & Cupferron & $0.2-50 \mathrm{nM}$ & $0.1 \mathrm{nM}$ & 20 \\
\hline SWSV & HMDE & Dihydroxynaphtalene & $0.01-1 \mathrm{nM}$ & $6 \mathrm{pM}$ & 21 \\
\hline SWSV & SMDE & p-cresol derivative & $1-10 \mu \mathrm{g} / \mathrm{L}$ & $0.06 \mu \mathrm{g} / \mathrm{L}$ & 22 \\
\hline SWSV & SMDE & 1,10 -phenanthroline & $0-0.5 \mu \mathrm{M}$ & $0.6 \mathrm{nM}$ & 23 \\
\hline LSSV & DME & Methyl orange & $1-80 \mu \mathrm{g} / \mathrm{L}$ & $0.3 \mu \mathrm{g} / \mathrm{L}$ & 24 \\
\hline SWSV & $\mathrm{HgFE}$ & 8-hydroxyquinoline & $1-100 \mathrm{nM}$ & $0.15 \mathrm{nM}$ & 25 \\
\hline DPSV & HMDE & Pyrogallol red & $0.8-80 \mu \mathrm{g} / \mathrm{L}$ & $0.1 \mu \mathrm{g} / \mathrm{L}$ & 26 \\
\hline Centri-V & GCE & Pyrogallol red & $20-100 \mathrm{nM}$ & $14 \mathrm{nM}$ & 27 \\
\hline DPSV & SMDE & Mandelic acid & $0-20 \mathrm{nM}$ & $1.4 \mathrm{pM}$ & 28 \\
\hline DPSV & CMCPE & CTAB & $0.5-500 \mu \mathrm{g} / \mathrm{L}$ & $0.04 \mu \mathrm{g} / \mathrm{L}$ & 29 \\
\hline DPSV & HMDE & Tiron & $0.01-21 \mu \mathrm{g} / \mathrm{L}$ & $0.006 \mu \mathrm{g} / \mathrm{L}$ & 30 \\
\hline LSSV & CMCPE & Morin & $\begin{array}{l}0.8-60 \mathrm{nM} \\
0.06-6 \mu \mathrm{M}\end{array}$ & $0.4 \mathrm{nM}$ & 31 \\
\hline LSSV & CMCPE & Alizarin violet & $0.006-10 \mu \mathrm{M}$ & $2 \mathrm{nM}$ & 32 \\
\hline DPSV & HMDE & Alizarin red s & $0.15-5 \mu \mathrm{g} / \mathrm{L}$ & $0.046 \mu \mathrm{g} / \mathrm{L}$ & 4 \\
\hline SWSV & $\mathrm{PbFE}$ & Alizarin red s & $2-50 \mathrm{nM}$ & $0.9 \mathrm{nM}$ & 33 \\
\hline DPSV & HMDE & Alizarin red s & $1-25 \mu \mathrm{g} / \mathrm{L}$ & $0.25 \mu \mathrm{g} / \mathrm{L}$ & 34 \\
\hline LSSW & DME & Azo compounds & $0.5-2.5 \mu \mathrm{M}$ & $0.15 \mu \mathrm{M}$ & 35 \\
\hline DPSV & $\mathrm{PbFE}$ & Alizarin red s & $2.65-20 \mu \mathrm{g} / \mathrm{L}$ & $\begin{array}{c}0.79 \mu \mathrm{g} / \mathrm{L} \\
\text { (with low } \\
\text { deposition time) }\end{array}$ & This study \\
\hline LSSV: Linear & stripping vc & metry & Differential pulse & ripping voltammetry & \\
\hline SWSV: Squal & e stripping v & imetry & V: Centri-voltamm & & \\
\hline DME: Droppi & rcury electro & SM & Static mercury dr & electrode & \\
\hline HMDE: Hang & ercury drop e & ode & Mercury film elec & & \\
\hline BiFE: Bismut & electrode & $\mathrm{Pb}$ & Lead film electrod & & \\
\hline GCE: Glassy & electrode & $\mathrm{CN}$ & E: Chemically mo & ied carbon paste elec & \\
\hline
\end{tabular}




\section{Experimental}

\subsection{Chemicals and Apparatus}

Molybdenum ICP standard (Merck, $1000 \mathrm{mg} / \mathrm{L} \mathrm{Mo}(\mathrm{VI})$ from $\left(\mathrm{NH}_{4}\right)_{6} \mathrm{Mo}_{7} \mathrm{O}_{24}$ in $\mathrm{H}_{2} \mathrm{O}$ ) was used for complexation and determination of molybdenum. The other chemicals were analytical reagent grade. Deionized water (18.2 M 2 ) obtained from ELGA PureLab Flex 2 ultra pure water system was used for preparation of all solutions.

Voltammetric measurements were performed using Ivium Compactstat potentiostat/galvanostat connected to a BASi C3 cell stand. A three-electrode system was used, which are lead film electrode ( $\mathrm{PbFE}$ ) supported with glassy carbon electrode (GCE) as working electrode, $\mathrm{Ag} / \mathrm{AgCl} / 3 \mathrm{M} \mathrm{NaCl}$ as reference electrode and platinum wire electrode as auxiliary electrode.

An Isolab ultrasonic bath was used for the cleaning of GCE.

$\mathrm{pH}$ measurements were made using Hanna HI-121 model $\mathrm{pH}$ meter with combined $\mathrm{pH}$ electrode. $\mathrm{pH}$ calibration was performed using standard buffer solutions prior to the measurements.

\subsection{Preparation of Lead Film Electrode (PbFE) and Measurement Procedure}

Afterwards the cleaning of GCE with alumina slurry on the felt plate, the GCE was ultrasonicated in 1:1 ethanol:ultra pure water and ultra pure water for 3 minutes, respectively. The GCE was activated in $0.1 \mathrm{M} \mathrm{pH} 5$ acetic acid/acetate buffer solution with waiting at $+1.2 \mathrm{~V}$ for $120 \mathrm{~s}$ and cyclic scanning between $-1 \mathrm{~V}$ and $+1 \mathrm{~V}$ until obtaining a stable baseline.

Lead film formation was performed in $0.4 \mathrm{mM} \mathrm{Pb}^{2+}$ and $0.1 \mathrm{M} \mathrm{pH} 5$ acetic acid/acetate buffer solution with waiting at $-1.45 \mathrm{~V}$ for $30 \mathrm{~s}$. Mo(VI)-ARS complex adsorption was made with electrodeposition at $-0.56 \mathrm{~V}$ for $60 \mathrm{~s}$ and the adsorbed complex was stripped of from $-0.56 \mathrm{~V}$ to $-1 \mathrm{~V}$.

\subsection{Sample Preparation Procedure}

Drinking water samples collected from Balıkesir and spiked with 1 and $3 \mu \mathrm{g} / \mathrm{L}$ molybdenum. All samples were diluted as 1:1 ratio and standard addition method was used for determination of molybdenum.

\section{Results and discussion}

\subsection{Voltammetric Behaviour of Mo(VI)-ARS Complex}

Differential pulse stripping voltammograms were recorded the absence and the presence of potassium chlorate to prove the catalytic effect. It can be seen from Figure 1, the peak current of $\mathrm{Mo}(\mathrm{VI})$-ARS complex is folded 7 times.

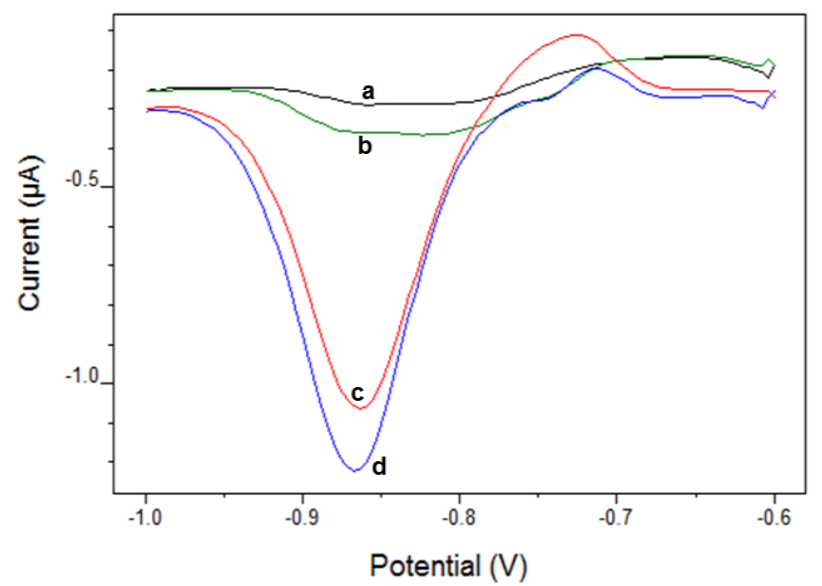

Figure 1. Stripping voltammograms of $7 \times 10^{-7} \mathrm{M}$ ARS (a), a $+10 \mu \mathrm{g} / \mathrm{L} \mathrm{Mo}(\mathrm{VI})(\mathrm{b}), \mathrm{b}+0.08 \mathrm{M} \mathrm{KClO}_{3}$ (c) and c $+15 \mu \mathrm{g} / \mathrm{L} \mathrm{Mo}(\mathrm{VI})(\mathrm{d})$ in the presence of $0.1 \mathrm{M}$ acetic acid/acetate buffer solution $(\mathrm{pH}=5)$ and $4 \times 10^{-4} \mathrm{M} \mathrm{Pb}^{2+}$. 
Moreover the cyclic voltammograms for various scan rates were recorded of the complex to prove the catalytic effect. The current function was plotted against to scan rates (Figure 2), the exponential decreasing depicts the catalytic system.

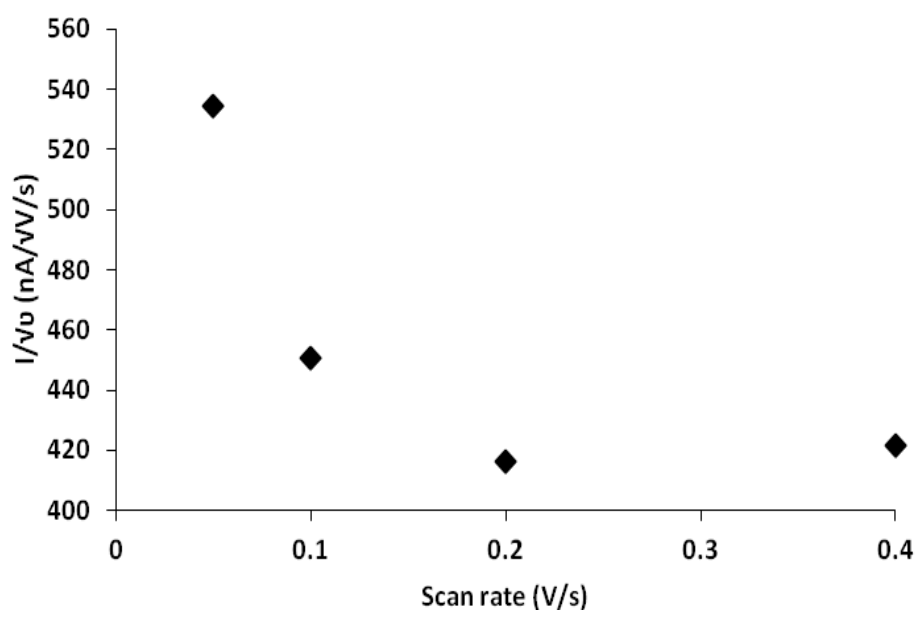

Figure 2. The current function $(\mathrm{I} / \mathrm{V} \mathrm{v})$-scan rate (v) graph $\left(4 \times 10^{-4} \mathrm{M} \mathrm{Pb}^{2+}, 8 \times 10^{-2} \mathrm{M} \mathrm{KClO}_{3}, 7 \times 10^{-7} \mathrm{M}\right.$ ARS and $5 \mu \mathrm{g} / \mathrm{L} \mathrm{Mo(VI)} \mathrm{in} 0.1 \mathrm{M} \mathrm{pH} 5$ acetic acid/acetate buffer solution. Scan rates: $50-400 \mathrm{mV} / \mathrm{s}$ )

As can be seen in Figure 3, Mo(VI) in the adsorbed Mo(VI)-ARS complex onto the electrode surface is reduced to $\mathrm{Mo}(\mathrm{V})$ by the driving force of potential. Afterwards $\mathrm{Mo}(\mathrm{V})$ oxidizes to $\mathrm{Mo}(\mathrm{VI})$ by chlorate then, Mo(VI)-ARS complex occurs again on the electrode surface. Therefore, the reduction process of $\mathrm{Mo}(\mathrm{VI})$ to $\mathrm{Mo}(\mathrm{V})$ called adsorptive catalytic procedure recreates.

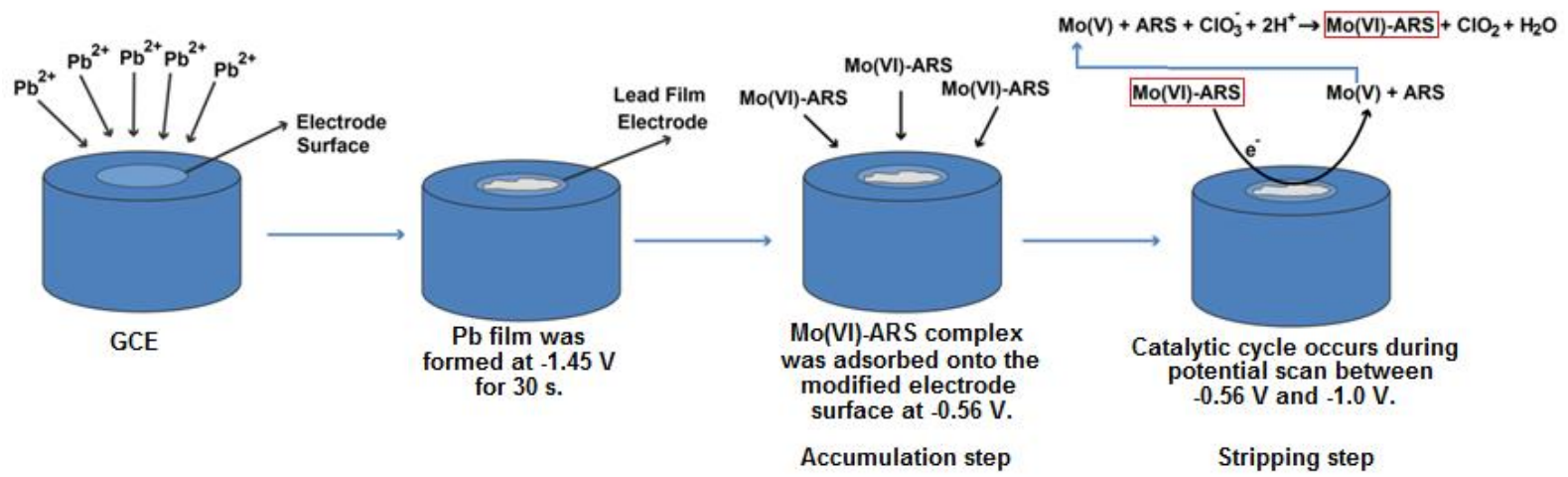

Figure 3. Schematic representation of the procedure and the electrode reactions

\subsection{Optimization studies for molybdenum determination}

Solution parameters which are $\mathrm{pH}$, concentration of ARS, potassium chlorate and lead and instrumental parameters which are deposition potential and time were optimized.

$\mathrm{pH}$ effect on peak current was investigated in the range of $3.50-5.75$ in acidic acid/acetate solutions. pH-peak current curve can be seen in Figure 4. The peak current has a maximum level at $\mathrm{pH}$ 5 , then decreased. Therefore $\mathrm{pH} 5$ was selected as optimum $\mathrm{pH}$. Also the peak potential $(\mathrm{mV})-\mathrm{pH}$ graph (not shown) was plotted and the slope of the graph is $57.6 \mathrm{mV}$ that is close to $59 \mathrm{mV}$. This situation shows the Mo(VI)-ARS electrode reaction realizes with equal proton and electron. 


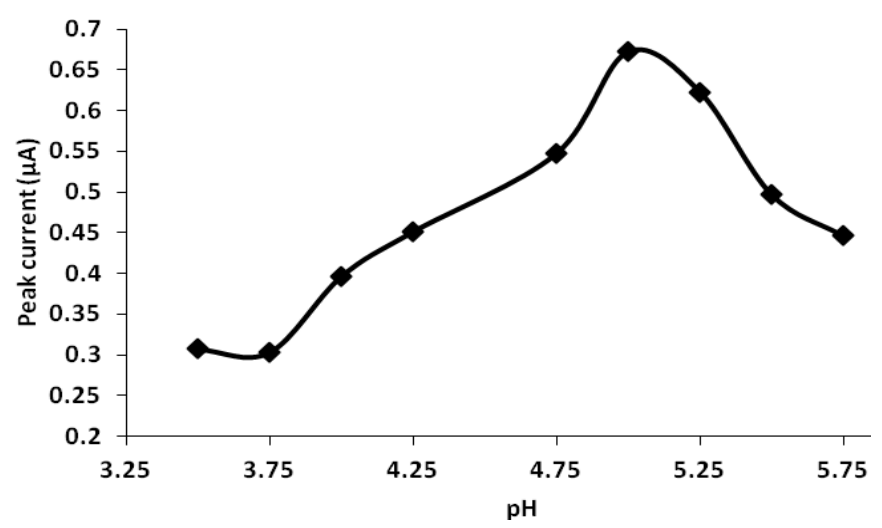

Figure 4. Peak current $(\mu \mathrm{A})$ - $\mathrm{pH}$ curve $\left(4 \times 10^{-4} \mathrm{M} \mathrm{Pb}^{2+}, 8 \times 10^{-2} \mathrm{M} \mathrm{KClO}_{3}, 7 \times 10^{-7} \mathrm{M}\right.$ ARS and $2 \times 10^{-8} \mathrm{M}$ $\mathrm{Mo}(\mathrm{VI})$ in $0.1 \mathrm{M} \mathrm{pH} 3.50-5.75$ acetic acid/acetate solutions)

The concentration of ARS is important for both formation of stable complex and the situation of competitive adsorption between free ARS and the ARS side of Mo(VI)-ARS complex. As can be seen the peak current $(\mu \mathrm{A})$-concentration of ARS $(\mu \mathrm{M})$ curve (Figure 5), the peak current was increased up to $0.7 \mu \mathrm{M}$, then decreased dramatically. It is supposed that the decreasing of peak current resulted from competitive adsorption between free ARS and the ARS side of Mo(VI)-ARS complex. Consequently, $0.7 \mu \mathrm{M}$ ARS was chosen as an optimal concentration.

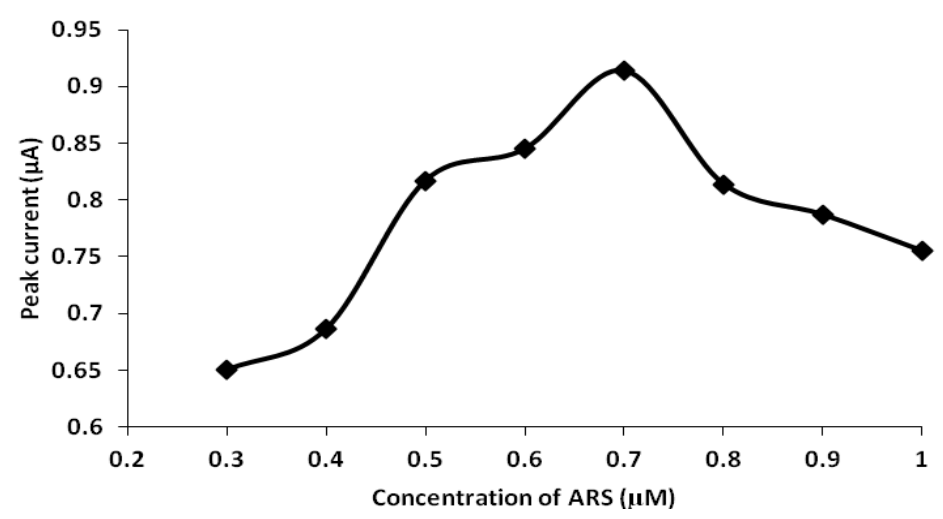

Figure 5. Peak current $(\mu \mathrm{A})$-ARS concentration $(\mu \mathrm{M})$ curve $\left(4 \times 10^{-4} \mathrm{M} \mathrm{Pb}^{2+}, 8 \times 10^{-2} \mathrm{M} \mathrm{KClO}_{3}\right.$ and $2 \times 10^{-8} \mathrm{M} \mathrm{Mo}(\mathrm{VI})$ in $0.1 \mathrm{M}$ pH 5 acetic acid/acetate buffer solution. ARS concentrations: $10^{-9}-10^{-6} \mathrm{M}$ )

Additionally, potassium chlorate concentration for catalytic effect and lead concentration for electrode modification were optimized. The effect of potassium chlorate concentration was investigated between $0.008-0.300 \mathrm{M}$, the peak current was increased up to $0.250 \mathrm{M}$ (not shown). However, the reason of sufficiency for determination of molybdenum in drinking water samples, 0.08 $\mathrm{M}$ potassium chlorate was randomly chosen as an optimal value. The lead concentration was evaluated between $1 \times 10^{-6}-8 \times 10^{-4} \mathrm{M}$, the peak current reached the maximum value with $4 \times 10^{-4} \mathrm{M}$, then decreased (not shown). Optimum lead concentration was selected as $4 \times 10^{-4} \mathrm{M}$.

The effect of deposition potential was examined between $-525 \mathrm{mV}$ and $-750 \mathrm{mV}$. The peak current was almost same to $-575 \mathrm{mV}$, then diminished (not shown). The optimum deposition potential was chosen as $-560 \mathrm{mV}$. The effect of deposition time was examined between 0-400 s. It was monitored that the peak current increased up to $400 \mathrm{~s}$ (not shown). Similarly to potassium chlorate optimization study because of the sufficiency of the method to applicable to drinking water samples, $60 \mathrm{~s}$ was chosen as optimum deposition time. 


\subsection{Validation and application of the method}

Differential stripping voltammograms were taken under optimum conditions (Figure 6) and calibration graph was plotted. The analytical range is between 2.65 and $20.00 \mu \mathrm{g} / \mathrm{L}$ with a regression equation of $I_{p a}(\mu \mathrm{A})=0.0358 C_{M o}(\mu \mathrm{g} / \mathrm{L})+0.6911(n=7, r=0.999)$. The limit of detection $\left(3 \mathrm{~s}_{\mathrm{y} / \mathrm{x}}\right)$ and limit of quantification $\left(10 \mathrm{~s}_{\mathrm{y} / \mathrm{x}}\right)$ were $0.79 \mu \mathrm{g} / \mathrm{L}$ and $2.65 \mu \mathrm{g} / \mathrm{L}$, respectively. The regression data analysis was given in Table 2 .

$\mu \mathrm{A}$

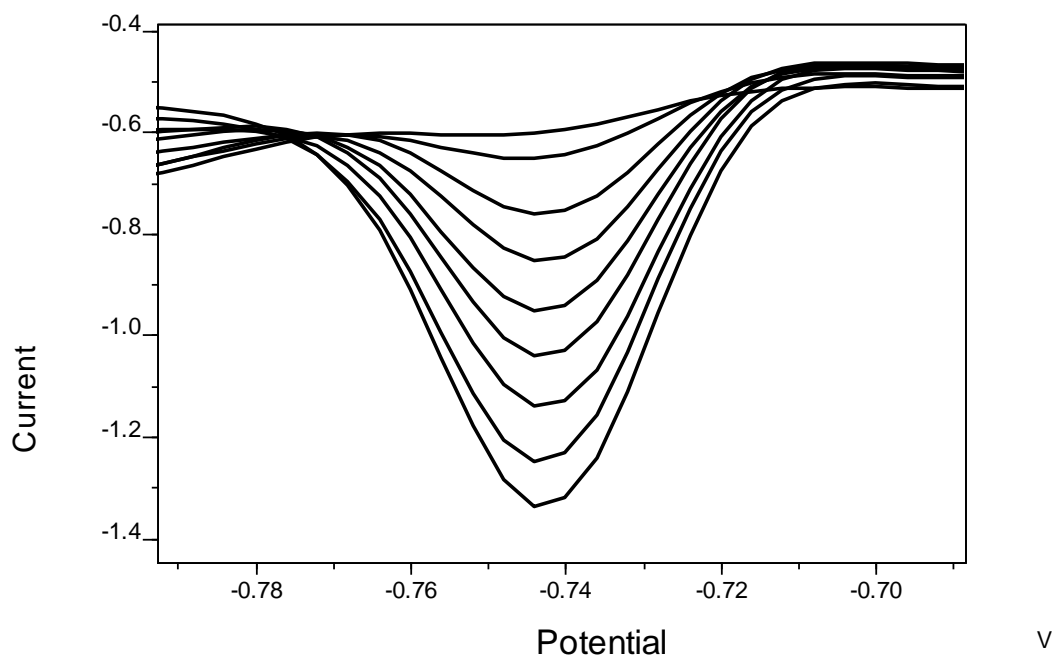

Figure 6. DPSV voltammograms with increasing $\mathrm{Mo}(\mathrm{VI})$ concentrations $\left(4 \times 10^{-4} \mathrm{M} \mathrm{Pb}^{2+}\right.$, $8 \times 10^{-2} \mathrm{M} \mathrm{KClO}_{3}$ and $7 \times 10^{-7} \mathrm{M}$ ARS in $0.1 \mathrm{M}$ acetic acid/acetate buffer solution at $\mathrm{pH} 5$. Mo(VI) concentrations: $0,0.5,2,5,8,11,14,17,20 \mu \mathrm{g} / \mathrm{L})$

Table 2. The regression data and validation analysis of voltammetric determination of molybdenum

\begin{tabular}{cc}
\hline Parameter & Value \\
\hline Slope $(\mu \mathrm{A} . \mathrm{L} / \mu \mathrm{g})$ & 0.0358 \\
Intercept $(\mu \mathrm{A})$ & 0.6911 \\
Standard deviation of slope $(\mu \mathrm{A} . \mathrm{L} / \mu \mathrm{g})$ & 0.0015 \\
Standard deviation of intercept $(\mu \mathrm{A})$ & 0.0192 \\
Standard error of estimate $(\mu \mathrm{A})$ & 0.0095 \\
Coefficient of variation $\left(\mathrm{R}^{2}\right)$ & 0.9986 \\
\hline
\end{tabular}

The interference effects of $\mathrm{Co}^{2+}, \mathrm{Cu}^{2+}, \mathrm{Mg}^{2+}, \mathrm{Cr}^{3+}, \mathrm{Fe}^{3+}, \mathrm{Sb}^{3+}, \mathrm{Cd}^{2+}$ and Triton X-100 were investigated with $2 \mu \mathrm{g} / \mathrm{L}$ molybdenum. 200 fold $\mathrm{Co}^{2+}$ and Triton $\mathrm{X}-100,150$ fold $\mathrm{Cr}^{3+}, 100$ fold $\mathrm{Cu}^{2+}$ and $\mathrm{Fe}^{3+}$ have no effect on the peak current according to $\pm \% 5$ change. On the other hand, $\mathrm{Mg}^{2+}, \mathrm{Sb}^{3+}$ and $\mathrm{Cd}^{2+}$ are seriously interfere, but the interference effect of $\mathrm{Mg}^{2+}$ and $\mathrm{Cu}^{2+}$ were eliminated with addition of the EDTA into the solution.

The real sample applications were given in Table 3. The recovery values of drinking water samples change between $98.3 \%$ and $110.7 \%$ and RSD values of these samples are between 3.86 and 14.86. Since the content of molybdenum in drinking water is very close to LOD, obtaining the high RSD value around the LOD is ordinary. 
Table 3. Real sample applications in drinking water

\begin{tabular}{cccc}
\hline $\begin{array}{l}\text { Spiked } \\
\text { Mo(VI) } \\
(\mu \mathrm{g} / \mathrm{L})\end{array}$ & $\begin{array}{c}\text { Found Mo(VI) } \\
(\mu \mathrm{g} / \mathrm{L})\end{array}$ & $\begin{array}{c}\text { Recovery } \\
(\%)\end{array}$ & $\begin{array}{c}\text { RSD } \\
(\%)\end{array}$ \\
\hline- & $0.74 \pm 0.11^{\mathrm{a}}$ & - & 14.86 \\
1 & $1.71 \pm 0.14^{\mathrm{a}}$ & 98.3 & 8.19 \\
3 & $4.14 \pm 0.16^{\mathrm{b}}$ & 110.7 & 3.86 \\
\hline & the mean of six measurements, ${ }^{\mathrm{b}}:$ the mean of three measurements
\end{tabular}

Since variations of influence quantities may affect a measurement result in both random and systematic ways, the qual itative performance characteristics of the measurements includes both trueness and precision,

Measurement uncertainty of a result is formed from a combination of systematic error and random error [36]. From this point of view the following equation for calculation of expanded uncertainty can be written;

$$
U \%=\sqrt{(|100-T \%|+2 x R S D \%)}
$$

where, $\mathrm{U}$ is expanded uncertainty of the result obtained in the method, $\mathrm{T}$ is the trueness and RSD is the relative standard deviation. In this equation, the term $|100-T \%|$ represents the total systematic error of the method while the term $2 x R S D \%$ represents the total random error. Six independent drinking water samples spiked with $12 \mu \mathrm{g} / \mathrm{L} \mathrm{Mo}(\mathrm{VI})$ were analysed by the proposed method. The mean of six measurements, T\% and RSD were calculated as $11.915 \mu \mathrm{g} / \mathrm{L}, 99.289 \%$ and $2.172 \%$, respectively. From the equation (1), U\% was calculated as 2.248 and it was transformed to U which was 0.268 . The result can be expressed as $(11.915 \pm 0.268) \mu \mathrm{g} / \mathrm{L}(\rho=0.025)$.

\section{Conclusions}

A new, selective, sensitive and accurate method for voltammetric determination of molybdenum was described. As far as we know there is no study that consisting of comprehensive validation and uncertainty examinations. Accuracy of the method has been successfully proved in drinking water samples for $95 \%$ confidence level.

The sensitivity of the method can be terrifically improved with increasing of potassium chlorate concentration or deposition time. As the limit values of molybdenum in drinking waters (the least: $10 \mu \mathrm{g} / \mathrm{L})$ are examined, the proposed method has good LOD value $(0.79 \mu \mathrm{g} / \mathrm{L})$. Because of this reason the higher concentrations of potassium chlorate or the higher deposition time were not used.

The proposed method is comparable to all voltammetric molybdenum determination methods used solid electrodes.

\section{ORCID}

Nail Deniz: 0000-0002-8883-5138

Lokman Liv: 0000-0001-8008-1012

Nuri Nakiboğlu: $\underline{0000-0002-5527-6472}$

\section{References}

[1] Wikipedia (2017). Molybdenum. https://en.wikipedia.org/wiki/Molybdenum. (accessed 22 March 2017).

[2] R. R. Mendel (2009). Cell biology of molybdenum, Biofactors 35, 429-434.

[3] D. G. Barceloux and D. Barceloux (1999). Molybdenum, J. Toxicol.: Clin. Toxicol. 37:2, 231-237.

[4] N. Nakiboglu, Z. Tünay and İ.Şahin (2011). Determination of molybdenum by adsorptive catalytic stripping voltammetry in the presence of alizarin red s and persulphate, Fresen. Environ. Bull. 20, 939944.

[5] S. B. Adeloju and P. Fleurdelis (1995). Adsorptive stripping voltammetric determination of ultratrace concentrations of molybdenum in biological and environmental materials on a glassy carbon mercury film electrode, Electroanalysis 7, 476-482. 
[6] Z. Gao and K. S. Siow (1996). Catalytic-adsorptive stripping voltammetric determination of molybdenum in plant foodstuffs, Talanta $\mathbf{4 3}, 719-726$.

[7] Y. C. Sun, J. Mierzwa and C. R. Lan (2000). Direct determination of molybdenum in seawater by adsorption cathodic stripping square-wave voltammetry, Talanta 52, 417-424.

[8] A. Safavi and E. Shams (1999). Selective determination of ultra trace concentrations of molybdenum by catalytic adsorptive stripping voltammetry, Anal. Chim. Acta. 396, 215-220.

[9] A. Safavi and E. Shams (2001). Electrochemical investigation of $\mathrm{Mo}(\mathrm{VI})-\mathrm{MTB}-\mathrm{ClO}_{3}{ }^{-}$system in phosphate buffer, Iran. J. Chem. Chem. Eng. 20, 96-101.

[10] S. Sander (1999). Simultaneous adsorptive stripping voltammetric determination of molybdenum(VI), uranium(VI), vanadium(V), and antimony(III), Anal. Chim. Acta. 394, 81-89.

[11] R. Piech, E. Niewiara, P. Paczosa-Bator and M. Szlósarczyk (2011). The determination of molybdenum in selected mushrooms by stripping voltammetry, Cent. Eur. J. Chem. 9, 352-356.

[12] R. Piech, B. Baś and W. W. Kubiak (2008). The cyclic renewable mercury film silver based electrode for determination of molybdenum(VI) traces using adsorptive stripping voltammetry, Talanta 76, 295-300.

[13] J. Wang, S. Thongngamdee and D. Lu (2006). Adsorptive stripping soltammetric measurements of trace molybdenum at the bismuth film electrode, Electroanalysis 18, 59-63.

[14] N. V. V. Jyothi, B. N. Kumar, S. Venkateswarlu and T. Balaji (2012). Adsorptive stripping voltammetric determination of molybdenum in medicinal leaves and soil samples, Int. J. Chem. Anal. Sci. 3, 15871589.

[15] J. C. de Andrade, A. M. de Almeida, A. R. Coscione and L. M. Alexio (2001). Determination of molybdenum in steel by adsorptive stripping voltammetry in a homogeneous ternary solvent system, Analyst 126, 892-896.

[16] J. C. de Andrade, A. M. de Almeida, L. M. Alexio, A. R. Coscione and M. F. de Abreu (2003). Direct voltammetric determination of $\mathrm{Mo}(\mathrm{VI})$ in plants: the need for a multivariate study of interferences, Anal. Chim. Acta. 487, 243-248.

[17] Z. Gao, K. S. Siow and A. Ng (1996). Catalytic voltammetric determination of molybdenum at a chemically modified carbon paste electrode, Electroanalysis 8, 1183-1187.

[18] Z. Q. Gao and K. S. Siow (1996). Adsorptive stripping voltammetric determination of traces of molybdenum in natural-water in the presence of alpha-benzoinoxime, Microchim. Acta. 124, 211-218.

[19] A. A. Ensafi, T. Khayamian and M. Atabati (2002). Simultaneous voltammetric determination of molybdenum and copper by adsorption cathodic differential pulse stripping method using a principal component artificial neural network, Talanta 57, 785-793.

[20] K. Jiao, W. Jin and H. Metzner (1992). Determination of molybdenum in soils and plants using the polarographic adsorptive complex catalytic wave of Mo(VI)-cupferron, Anal. Chim. Acta. 260, 35-43.

[21] H. Li and R. B. Smart (1997). Square wave catalytic stripping voltammetry of molybdenum complexed with dihydroxynaphtalene, J. Electroanal. Chem. 429, 169-174.

[22] I. C. S. Fraga, P. M. E. Farias and A. K. Ohara (2000). Determination of molybdenum in the presence of 2-(2-benzothiazolylazo)-p-cresol by catalytic-adsorptive stripping voltammetry, Fresen. J. Anal. Chem. 366, 307-309.

[23] F. Quentel (1999). Voltammetric study of molybdenum in the presence of phenanthroline, Electroanalysis 11, 1355-1360.

[24] Z. L. Jiang, Q. Gong and M. D. Liu (1994). A new catalytic method for the determination of trace amounts of molybdenum with linear scan voltammetry at a DME, Anal. Lett. 27, 1945-1954.

[25] M. M. P. M. Neto, M. M. G. S. Rocha and C. M. A. Brett (1994). Square wave adsorptive stripping voltammetry of molybdenum(VI) in continious flow at a wall-jet mercury film electrode sensor, Talanta 41, 1597-1601.

[26] A. A. Ensafi, T. Khayamian and S. S. Khaloo (2004). Application of adsorptive cathodic differential pulse stripping method for simultaneous determination of copper and molybdenum using pyrogallol red, Anal. Chim. Acta. 505, 201-207.

[27] S. Koçak and F. N. Ertaş (2013). Centri-voltammetric determination of molybdenum, Anal. Method. 5, 741-747.

[28] K. Yokoi and C. M. G. Van den Berg (1992). Simultaneous determination of titanium and molybdenum in natural waters by catalytic cathodic stripping voltammetry, Anal. Chim. Acta. 257, $293-299$.

[29] M. Stadlober, K. Kalcher and G. Raber (1997). A new method for the voltammetric determination of molybdenum(VI) using carbon paste electrodes modified in situ with cetyltrimethylammonium bromide, Anal. Chim. Acta. 350, 319-328.

[30] A. A. Ensafi and S. S. Khaloo (2004). Determination of traces molybdenum by catalytic adsorptive stripping voltammetry, Talanta $65,781-788$. 
[31] P. H. Deng, Y. I. Feng and J. J. Fei (2011). A new electrochemical method for the determination of trace molybdenum(VI) using carbon paste electrode modified with sodium dodecyl sulfate, J. Electroanal. Chem. 661, 367-373.

[32] P. Deng, J. Fei, J. Zhang and Y. Feng (2011). Determination of molybdenum by adsorptive anodic stripping voltammetry of molybdenum-alizarin violet complex at an acetylene black paste electrode, Food Chem. 124, 1231-1237.

[33] K. Tyszczuk and M. Korolczuk (2008). Adsorptive stripping voltammetric determination of trace concentrations of molybdenum at an in situ plated lead film electrode, Anal. Chim. Acta. 624, 232-237.

[34] R. Jugade and A. P. Joshi (2005). Trace determination of Mo(VI) by adsorptive cathodic stripping voltammetry, Acta Chim. Slov. 52, 145-148.

[35] G. V. Prokhorova, V. M. Ivanov and G. A. Kochelaeva (2000). Azo compounds as reagents for the voltammetric determination of molybdenum(VI), J. Anal. Chem. 55, 669-672.

[36] A. Menditto, M. Patriarca and B. Magnusson (2007). Understanding the meaning of accuracy, trueness and precision, Accredit. Qual. Assur. 12, 45-47.

\section{A C G \\ publications \\ (C) 2017 ACG Publications}

